\title{
Restorative Justice and Social Rehabilitation of The Children in Conflict With The Law (A Study on the Involvement of Government Institutions in the Rehabilitation Process of Children in Conflict with the Law in Banyumas Regency)
}

\author{
Tri Wuryaningsih", Sunyoto Usman² \\ ${ }^{1}$ Faculty of Social and Political Sciences, Jenderal Soedirman University, Purwokerto, Indonesia \\ (Triwury@yahoo.com) \\ ${ }^{2}$ Faculty of Social and Political Sciences, Gadjah Mada University, Yogyakarta, Indonesia \\ (sunyotousman@yahoo.com)
}

\begin{abstract}
Restorative justice approach by way of diversionis considered as the best approach to resolve the case forc hildren in conflict with the law. Diversion is an actor actsto divert or put child criminals out of the criminal justice system. In Banyumas, children in conflict with the law are resolved by way of diversion, the majority returned to the parents, to be educated and supervised in order not to commit criminal acts again. Therefore, responsibility for social rehabilitation of children in conflict with the law left to the family and only a small portionis sent to the child's social rehabilitation center owned by the government. This study aims to examine how the involvement of government agencies in the process of social rehabilitation of children in conflict with the law.
\end{abstract}

Keywords: Restorative justice, social rehabilitation, children in conflict with the law.

\section{Introduction}

One of the problems faced byIndonesian child is a child in conflict with the law, (children in conflict with the law), a term used internationally to "a person under the age of 18 who are dealing with the criminal justice systemis concerned because the suspected or accused of committing a crime" (http://www.ypha.or.id/web, 2011). In the Convention on the Rightsof the Child, children in conflict with the law are categorized into groups of children in need of special protection (CNSP) and categorized as vulnerable groups. Imprisonment or restriction of freedom as far as possible is avoided. Child settlement' approaches to restorative justice by way of diversion. Diversion is an actor acts to divert or put child criminals out of the criminal justice system (Bynum, inMarlina, 2007). Restorative justice approach by wayof diversionis considered as the best approach to resolve the case for children in conflict with the law. Through this approach, the rehabilitation of the child's social responsibility is no longer in prison, but there is the rehabilitation of the child and family agencies. That ought to be studied is, when the responsibility is left to the social rehabilitation of the family, how the role and involvement of government agencies in the process? Of particular concern is the disposal of the child by way of diversion actually is a form of denial of the state's responsibility towards children in conflict with the law. Meanwhile, the social rehabilitation process fully submit to the family is not an easy thing to do, given the many studies show that families often participate precisely above the delinquency of children and adolescents who cause them to be in conflict with the law (Kartono, 1992; Mann and Reynolds, 2006; Rosenbaum, Moran, \& Pettit in Kurnisari Chang et al., 2009) . The issue of rehabilitation of children in conflict with the law are 
resolved by way of diversion and handed over to the parents throughout the authors' knowledge has not been done. Studies that have been done is a review of the child's rehabilitation process in social rehabilitation institutions owned by the government (Kurnisari, 2009), done from the perspective of jurisprudence like seeing the implementation of diversion in the police service (Rambe, 2010) and legal protection of children in conflict with the law in the judicial process (Nugroho, 2009).

\section{Research Method}

Qualitative research was conducted to obtain in-depth information (Denzin and Lincoln, 2009) about the involvement of government agencies in Banyumasin the rehabilitation of children in conflict with the law. Informants were selected using purposive sampling technique. Data collection was conducted from December 2013-April 2014 by way of observation, indept-interview, and documentation. Data were analyzed using qualitative descriptive analysis with interactive analysis model developed byMiles and Huberman (1994).

\section{Results And Discussion}

Social rehabilitation and developmentis are creation of the process to enablea person is able tocarry out normal social functionin society (Kemenkumham, 2012). Snar stated that Rehabilitation philosophy is based on the concept of parent'spatria, where states provide care and protection to children as be fits the parents to their children. On the basis of this philosophyof handling children in conflict with the law is done through the efforts ofthe best interests ofthe child. The children viewed more as victims of circumstance and environment is rather than as perpetrators. Rehabilitation thus aims to support and provide treatment within the scope ofthe individual (Dermawan: 2009). In Banyumas, the numbers of children in conflict with the law are 80 children during the years 2009-2011. From this amount, which is processed through the justice restorative justice and returned to parents (families) are 57 children (Reported by PPT PKBGA Banyumas Regency in 2012). Childrenin conflict with the law are resolved by way of diversion majority returned to the parents, to be educated and controlled so as not committing a crime again. Therefore, responsibility for social rehabilitation of children in conflict with the law left to the family and only a small portion is sent to thechild's social rehabilitation center owned by the government. Based on the Memorandum of Understanding of the five ministries and the Indonesian National Police (Kemenkumham, 2012), there are somea gencies that should be responsible for the social rehabilitation of children in conflict with the law at the local level, namely: Children Correctional Center; Department of Social Affairs, Manpower and Transmigration; Department of Education; and Department of Health. By taking the case in Banyumas, how is the involvement of various government agencies in the rehabilitation of children in conflict with the law? The findings of the research are summarized into the following four themes of this discussion.

\subsection{Correctional Center For Children Purwokerto: "The budgetand 'WeakFree Fall'CommunityAdvisor Quality"}

Correctional Center for Children Purwokerto is a representation of the central government, namely the Ministry of Justice and Human Rights in the regions. The institute shall provide guidance through existing social counselors at the agency or in cooperation with third parties, such as boarding schools, scouts, etc. 
Guidance on children in conflict with the law carried out for 6 months, either by home visits or asks the child must report once a week. Nevertheless, as told by $\mathrm{Kmr}$, one of the childrenin conflictwith the law that for just one time coaching visited by officers Correctional Center for Children Purwokerto and only a few times he came (mandatory reportin ) to the office. Coaching he received only advices from existing officers and have never received such training and other workshops. Guidance on children in conflict with the law given by the Correctional Center for Children Purwokerto is not optimal. Head of ChildGuidanceClient Sub-Section in CorrectionalCenter for Children Purwokerto said: "besides the work that covers a wide area of Banyumas, Pubalingga, Banjarnegara, Cilacap, Kebumen and Purworedjo, budget support provided by the government is very small, then he deifying " budget freefall ". In terms of community resource supervisor, although considered to be sufficient in quantity, but the quality is still considered weak. In addition, the preparation of planning activities and budgeting who never communicated with community mentors, making existing activities in the agency often cannot match the problems and needs. However, these conditions will greatly affect the quality of the guidance provided".

\subsection{Department of Social Affairs, Manpower and} Transmigration: "We Do not Have Data Base"

The onlyactivities undertaken Department of Social Affairs, Manpower, and Transmigration Banyumas relating to children in conflict with the law is facilitating delivery of children in conflict with the law to Panti Sosial Marsudi Putera Antasena that child rehabilitation center owned by the Ministryof Social Affairs is located in Magelang. Activities carried out twice a year. Head of Social
Rehabilitation Section in Department of Social Affairs, Manpower, and Transmigration Banyumas said: "besides, due to lack of budget support, it is done because the tailor future training provision made by the PSMP Antasena, for six months". According with statement of Head of Women and Child Protection Unit in Banyumas Police that it certainly can not answer the problem of children in conflict with the law in Banyumas whose case lasted almost every day and increase the quantity and quality over time. The number of cases of children in conflict with the law in Banyumas, yet integrative handled involving various agencies concerned with these problems. Settlement ofthe caseby wayof diversionin Banyumas Police, the agency has not been involved. Instead, the agency also creatively develops communication and coordination with agencies related to the problem. The phrasethat "we do not have a database" of children in conflict with the law in Banyumas, used as a reasonnot to develop activities and rehabilitation programs children in conflict with the law on the agency. In fact, the data is easily accessible in Banyumas Police. Weak involvement of the agency in the process of rehabilitation of children in conflict with the law is also delivered by the escort agency child in Banyumas. As told by One of children volunteer companion said: "we always trouble when the police have to follow the recommendations of the children who had to be sent to a rehabilitation center for children. Department of Social Affairs, Manpower and Transmigration Banyumas always answer no budget, but the child should immediately receive coaching". Weak understanding of bureaucrats against the central government's policies relating to the handling of children in conflict with the law, such as the Memorandum of Understanding of the five 
ministries and the Indonesian National Police contributed to the weakness of their creativity to develop programs and activities. Hidayat and Sucherly research shows that a lack of creativity and a tendency to refer to the procedure is a common feature of civil servants in Indonesia (Kumorotomo, 2008). As told by Head of Women Empowerment and Child Protection that mutations government employees within theBanyumas Government too quickly regarded as one of the causes of lack of understanding and control of matter at each department, because the employee is considered not to have enough time to learn and master the field that should be handled. Referring to the opinion Lenvine (1990), that the responsiveness, responsibility and accountability are three indicators that must be met in every product of public service is in a democracy.

\subsection{School: "We Fear Protested by the Other Parents"}

School as a representation of the Department of Educationis an institution that is directly related to the children. Children in conflict with the law school status still often get excluded from school sanction. HS, one of the children told me that he was asked to resign from the school when the school knew he was involved in obscene acts with his girl friend. This actionre flects that the handling of children in conflict with the law made by the school did not promote the best interests of the child. Opportunity to continue the ideals and a better future is closed to them. As told by some of the principals in Banyumas that the reason given by the school for this action is "we fear protests by other parents, because if not removed feared to be a bad influence on other student". The act of makinga child feels isolated and useless. This would have the potential to encourage children to do acts of delinquency or criminal acts again. Labeling according to the theory developed by Lemert, that person becomes deviant because the labeling processgiving the nick name, seal, label, brand-which was given to her community. At first the person committing their regularities, called the primary aberrations. A result of their regularities-such as theft, fraud, immorality, and bizarre behavior-the perverts then is labeled thieves, fraudsters, rapists, naughty ladies, crazy people. In response to labeling by others then the culprit primary aberrations then defines him self as perverts and repeats its perversitysecondary irregularities-so start embracing a deviant life style that results in adeviant career (Sunarto, 1998). School action on children in conflict with the law is away from the principles that should be put forward in the protection of children, namely nondiscrimination, the best interests ofthe child, the right to live and thrive and respect for children. Head of Child Protection Subsection (Kasie Perlindungan Anak, Bapermas PKB) said that teachers understanding of the rights of children are still veryweak, even the very few teachers who know about the CRC or the Child Protection Act. If you look at the data, until 2011, the number of teachers trained CRC, only 45 people (Base Line Data Kota Layak Anak, Kabupaten Banyumas 2012). Amount is not comparable with the number of teachers employed in Banyumas in the same year, for 18.458 people (Sistem Informasi Gender dan Anak Kabupaten Banyumas 2012).

\subsection{Departmentof Health (RSUDBanyumas);} "There Is No Policy Acquisition Costs"

Banyumas District General Hospitalas are presentation of Banyumas District Health Officeh as the obligation to provide health care to children in conflict with the law. However, this obligation has not been well understood by the stake holders in the 
Departmentof Health or in the hospital. AK, the father of one of the children in conflict with the law tells us that he was recommended by the Correctional Center for Children Purwokerto to take his son to a psychologist at the hospital to get psychological therapy. In accordance with the recommendation of a psychologist who handle, therapy should be done at least10 times. However, after 2 times the therapy, he was forced to stop because it could not afford the cost. Regarding this problem, RW one who handles child psychologist explained that the hospital until now could not waive the fee for such patients, because there is no such policy and local regulations from Banyumas Government. However, patients can use the Community Health Insurance Card (assurance) toget a fee waiver. Unfortunately, not all patients can get the card. Bureaucracy is considered a convoluted is often there a son people do not want to take care of the card. Not the completion of handling children in conflict with the law with special needs, that it should receive intensive therapy often have an impact onthe failure of the on going rehabilitation of child. Children re-create the problem and dealing with the law again. One of the children named DR, sonof AK in the end had tobe sent in prison, children as achild repeatedly state after committing a crime. From administration of the childin conflict with the law who allegedly suffered psychological disorders should be done through the various stages of intervention, namely: examination (diagnosis and prognosis), treatment, rehabilitation, development and improvement of mental health. Dinar Sari Eka Dewi, lecturer in Clinical Psychology of Muhammadiyah University Purwokerto stated that the procedure begins with the examination and intervention approach, followed by assessment, observation, interview, home visit; make a planof intervention (program), the therapeutic contract, and implementation of interventions not only on the individual concerned but also on the family environment and surrounding communities.

\section{Conclusion}

Banyumas Government commitment, which is represented by The Departmentof Education; The Department of Social Affairs, Manpower, and Transmigration and The Departmentof Health towards the rehabilitation of children in conflict with the law post diversion, is very low. Likewise with Correctional Center For Children as a representative of the central governmentin the regions also show the same thing. The small budget support, the absence of local regulationsas an umbrella law on the protection of children, the lackof resources which has the capability of civil servants has become a series of weak commitment to the cause of the. Associated with the process of rehabilitation of children in conflict with the law, the role of these institutions will be vital to the enactment of Law No.11 of 2012 on the Juvenile Justice System to be implemented in Indonesia starting in July 2014. Therefore, bureaucratic reform coupled with budget support needs that are not adequately be negotiable by both central and local government.

\section{References}

(1) __ 2012, Base Line Data Kota Layak Anak Kabupaten Banyumas, Badan Pemebrdayaan Masyarakat, perempuan dan Keluarga Berencana Kabupaten Banyumas (2) , 2012, Sistem Informasi Gender dan Anak Kabupaten Banyumas, Badan Pemebrdayaan Masyarakat, Perempuan dan Keluarga Berencana Kabupaten Banyumas 
(3) Denzin, Norman K and Lincoln, Yvonna S. (Editors), 1994, Handbook of Qualitative Research (second edition), Thousand Oaks, London: Sage Publication

(4) Dermawan, dkk., 2009, Analisis Situasi Anak yang Berhadapan dengan Hukum di Indonesia, Unicef-UI Tahun 2006 - 2007, Jakarta

(5) Herlina, Apong, 2011, Sistem Perlindungan Anak berkonflik dengan hukum, dalam Makalah Seminar Advokasi Implementasi Kebijakan Keadilan Restoratif dalam Penanganan Anak Berkonflik Dengan Hukum, KPAI, Semarang, 2022 Juli

(6) Kartono, Kartini, 1992, Patologi Sosial 2: Kenakalan Remaja, Cetakan kedua, Rajawali, Jakarta

(7) Kumorotomo, Wahyudi, 2008, Pelayanan yang Akuntabel dan Bebas KKN, dalam buku Mewujudkan Good Governance melalui Pelayanan Publik, Editor Agus Dwiyanto, Cetakan Ketiga, Yogyakarta: Gadjah Mada University Press

(8) Kurniasari, Alit, dkk., 2009, Pelayanan dan Rehabilitasi Sosial Anak di Panti Sosial Marsudi Putra (PSMP): Evaluasi Program Penanganan Anak Nakal, Cetakan 1, Jakarta: P3KS Press

(9) Lenvine, Charles H., et al., 1990, Public Administration: Chalenges, Choices, Consequences, Illionis: Scott Foreman

(10) Mann, E.A. dan Reynolds A.J., 2006, Early Intervention and Juvenile Delinquency Prevention: Evidence from Chicago Longitudinal Study, dalam Social Work Resarch September 2006 30:3 pp. $153-167$

(11) Marlina, 2007, Diversi dan Restorative Justice sebagai Alternatif Perlindungan terhadap Anak yang Berhadapan dengan Hukum, dalam
Mahmul Siregar dkk, Pedoman Praktis Melindungi Anak dengan Hukum Pada Situasi Emergensi dan Bencana Alam, Pusat kajian dan Perlindungan Anak (PKPA), Medan

(12) Miles, Matthew B and A. Michael Huberman, 1988, Qualitative Data Analysis: A Soucebook of New Methods, Seventh Printing, California: Sage Publications

(13) Nugroho, Okky Chahyo, 2009, Perlindungan Anak yang Berhadapan dengan Hukum dalam Proses Peradilan (Studi Kasus di Wilayah Hukum Jakarta Barat), Tesis Program Pascasarjana Departemen Kriminologi, Fakultas Ilmu Sosial dan Ilmu Politik, Universitas Indonesia, Depok

(14) Rambe, Rahmad Syahroni, 2010, Peran Penyidik dalam Penerapan Diversi terhadap Anak yang Berhadapan dengan Hukum (Suatu Studi di Kota Medan), Skripsi Fakultas Hukum Universitas Sumatera Utara, Medan

(15) Sunarto, Kamanto, 1998, Pengantar Sosiologi, Cetakan ke-2, Lembaga Penerbit Fakultas Ekonomi Universitas Indonesia, Jakarta

(16) http://www.ypha.or.id/web/Foundation for Child Rights Monitoring: Children in Conflict with the Law in the Perspective of International Human Rights Law, December 2011 